\title{
Menace II Society? Urban Poverty and Underclass Narratives in American Movies
}

\section{Thomas Halper and Douglas Muzzio}

\section{(2) OpenEdition \\ Journals}

Electronic version

URL: https://journals.openedition.org/ejas/10062

DOI: 10.4000/ejas.10062

ISSN: 1991-9336

Publisher

European Association for American Studies

\section{Electronic reference}

Thomas Halper and Douglas Muzzio, "Menace II Society? Urban Poverty and Underclass Narratives in American Movies", European journal of American studies [Online], 8-1 | 2013, document 5, Online since 22 August 2013, connection on 08 July 2021. URL: http://journals.openedition.org/ejas/10062 ; DOI: https://doi.org/10.4000/ejas.10062

This text was automatically generated on 8 July 2021.

Creative Commons License 


\title{
Menace II Society? Urban Poverty and Underclass Narratives in American Movies
}

\author{
Thomas Halper and Douglas Muzzio
}

\begin{abstract}
"Living in the richest country in the world, wouldn't you think you'd have a better life?"

Randy Newman, "Piece of the Pie"
\end{abstract}

There they are.

Thirty at the corner.

Black, raw, ready.

Sores in the city

that do not want to heal.

-Gwendolyn Brooks, “The Blackstone

Rangers"

\section{Prologue}

"For the poor always ye have with you" (John 12:8), cautioned Jesus, and early moviemakers took this maxim to heart, using the plight of the poor as the core of numerous films. The movies' poor, however, were not just any poor. In an era when the nation was transformed by industrialization and immigration, movies conceived poverty very largely as an urban phenomenon. Indeed, the preoccupations of the urban poor drove the young movie industry, which in film after film depicted the poor's deprivations and fears, hopes and joys. Would they lose their jobs? Could they feed their children? Suppose illness or accident struck? What daily humiliations did they endure? What if they got in trouble with the law? From these concerns, concrete and mundane but resonating powerfully with audiences, moviemakers concocted innumerable plots, mostly sentimental (Gold Is Not All, 1910) but sometimes harsh and unforgiving (Musketeers of Pig Alley, 1912). "I embrace the common," announced 
Emerson, "I explore and sit at the feet of the familiar, the low ... the meal in the firkin, the milk in the pan, the ballad of the street" (I: 67-68), and early moviemakers heeded his call.

If the problems posed by the films were social, the solutions were nearly always personal. Typically, a combination of sturdy bourgeois virtues (industriousness, thrift, temperance) plus a soupçon of luck was all that was required. The tone was upbeat, and because no great confrontation with the State or the Market was called for, the movies left viewers hopeful and optimistic. If inevitable progress was slain in Europe by World War I, it remained alive and well in the United States.

The movies' interest in the urban poor waned somewhat in the prosperous 1920s, when the emphasis was more on rags-to-riches success (The Darling of New York, 1923; Sweet Rosie O'Grady, 1926). With the Depression, however, poverty returned to center stage, and a series of social problem films (Dead End, 1937; Angels with Dirty Faces, 1938) portrayed the urban poor as victims of injustice perpetrated by large social and economic plutocratic forces. But it was not enough that these movies induced their audiences to identify with the needy and the outcasts; viewers had also to be inculcated in a rough ideology supporting social programs to help them. As the Depression was superseded by World War II and then by post-war abundance, however, movies turned away from urban poverty, focusing on other concerns. In books, too, the elemental fear that poverty could strike anyone was displaced by best-selling lectures against private affluence and warnings about the hollowness of bourgeois life. Not even President Johnson's high-profile War on Poverty could persuade Hollywood to return to its old themes.

5 Four generalizations may be used to describe this long period. First, movies were audience driven. Though often deconstructed as social statements (see Bourget) or works of art (see Ginsburgh and Weyers), movies have always been, above all, commercial undertakings. Their initial audience was chiefly the urban working class and poor, who patronized nickelodeons. The character of the audience did not change radically until the poor began to decline in number and to own televisions, which served as a cheap alternative entertainment source.

6 This meant that movies would not only focus on the cities' lower orders but would present them in positive ways. There was no money to be made by insulting your customers. Negative narratives, as a consequence, possessed very little traction. Though fashionable with academics (Brigham), reformers (Sanger), and the popular press, for example, eugenics films denigrating the poor were rarely shown at mainstream theatres (but see Pernick). Though a vulgarized Social Darwinism retained its vitality among newspapers (Holt 47) and many of the well-to-do (Commager 89), movies never claimed that the inability of the poor to compete in the marketplace would somehow generate progress by promoting the survival of the fittest. Nor did movies swallow an acquisitive business ethos that was sufficiently potent to give rise to a small industry of debunkers rejecting wealth as an indicator of virtue and poverty of vice (see S. Lewis; Veblen; Mencken).

7 Second, movies during this period almost without exception subscribed to what later came to be known as the culture of poverty thesis. Rousseau may have originated this thesis when, in A Discourse on the Origin of Inequality, he described the poor as driven by their destitution to thievery, prostitution, and other immoral conduct, which in turn 
corrupted them and induced them to corrupt their children. In its more modern dress, the thesis conceives poverty as not only the "absence of something," but

also something positive in the sense that it has a structure, a rationale, and defense mechanisms without which the poor could hardly carry on. [Poverty] is a way of life, remarkably stable and persistent, passed down from generation to generation in long family lines (0. Lewis 1966 xxiv; also Harrington 16-17; Seligman 16).

8 Poverty may have structural causes endemic to the larger economic system, but underclass films in these years generally did not dwell on these factors, but instead spent time on the cluster of attitudes (like fatalism) and behaviors (like seeking immediate gratification) that constituted a rational accommodation to the situation, but also discouraged and impeded efforts to improve the situation (Lewis, Children 19). Movie characters finding themselves in an underclass community learned underclass attitudes and behaviors, conforming to these sets of standards as they rejected those of society at large. This tendency toward pessimism and low aspirations is accentuated by the physical setting of poverty, which limits the set of persons whose life experiences appear relevant in forming the characters' own beliefs and goals (Dalton, Ghosal, and Mani) as it distances them from upwardly mobile opportunities. Acquired naturally, these underclass attitudes and behaviors are said to seem normal, sensible, workable, and honorable, and may therefore be impervious to change. Accepting this thesis, even the Progressives tried "to take the poverty out of people, as well as to take the people out of poverty" (J. Patterson 86).

The culture of poverty thesis has come under fierce and sustained attack. ${ }^{1}$ Whatever its validity, however, the thesis remains a compelling paradigm (Kuhn), and powerfully commends itself to movies: it is so easy to grasp that viewers at once receive it as obvious common sense; and it frames narratives as struggles between individuals and their environment, an irresistible organizing principle beloved by story tellers and audiences, and immortalized in works by Dickens, Zola, Dreiser, and countless others.

10 Third, movies have tended to find vice more entertaining than virtue. This was not exactly unprecedented. Milton's Satan in Paradise Lost is much more interesting than God. The movies' infatuation with sin goes back at least to The Great Train Robbery (1904) and, whether prettified or presented in ugly splendor, has never faltered. Beside the grotesques' vitality, the conventional persons' dullness renders them as easy to ignore as cold toast.

11 Fourth, that poverty was above all an urban affliction was accepted as a given, though in truth rural poverty was more widespread. Yet for moviemakers the specific etiology of urban poverty remained unclear. Do cities make people poor or simply attract the poor? That is, as a consequence of weak labor markets and inadequate social services, does the city reduce the lower middle and working classes to indigence? Or does the city make promises that seduce the poor from the countryside or from foreign lands, for instance, the lure of real or imagined jobs or public subsidies? Moviemakers were not policy makers. For them, either narrative was quite acceptable.

12 The obvious irony is that cities historically have been perhaps the most potent weapon against poverty (see Glaeser). Enterprises are attracted by the promise of increased productivity (from economies of scale in production and easy access to labor, markets, and financing), and workers are attracted by better pay and more secure employment (made possible by the increased productivity and the presence of multiple employers). The dilemma facing cities has always been that to the extent that they improve the lot 
of the poor, they will attract more of them, recycling the problem. For moviemakers, this was of no interest.

The movies selected for discussion in this essay are all American films that represent American life at the time of their production. Foreign, historical, and documentary movies are excluded. The movies chosen are considered to be significant commercially or critically or because they typified their genre. Commercial success is an indicator that the movies resonated widely with the public; critical acclaim points at exerting influence on future movies. The movies selected are also city-centered, that is, the city actively participates in shaping character and plot, rather than city-set, where substitution of another background locale would alter only the details, as well as poor/ underclass-centered and not merely poor/underclass set. Films focusing on police or vigilantes, for example, are therefore excluded. There is an element of subjectivity in this, but these selection schema are standard in discussions of films (see Sanders 3-12; Doherty 1-20).

\section{Scene I: The Deserving and the Undeserving Poor}

14 The poor may always be with us, but America has never imagined that all poor are created equal. Rather, there are what Jacob Riis called the "honestly poor" and the "paupers" or what modern observers recognize as the deserving and the undeserving poor (see Cook and Barrett; Gilens; Goren; McClosky and Zaller; J.Patterson). The deserving poor deserve our pity and our assistance, for their plight is not their fault. Illness, accident, or some other personal calamity outside their control has done them in, and there is little they can do for themselves. Because they understand that they are victims of misfortune and not of the economic or social system, they do not blame society, but instead continue to applaud its values. The undeserving poor, on the other hand, have through their own vices -- sloth, improvidence, dishonesty -- brought about their own suffering. Their demands for aid, it is said, merely demonstrate their blindness to the causes of their own downfall. What they really need -- though they would never concede it -- is not money (which cannot solve their problem but only briefly ameliorate it) but virtue (which alone can transform them into productive members of the community). The undeserving poor deserve little, perhaps just enough to sustain life, perhaps not even that. The undeserving poor today are included within the label of the underclass (Jencks 23). The underclass, however, is not limited to the poor. Gangsters and hustlers, for example, may earn good money, and yet be counted among the underclass. What matters is that, like the undeserving poor, they quite openly reject mainstream values and virtues, and in this sense, may seem to live apart from general society, outside or beneath its class system. ${ }^{2}$

The underclass, in a sense, are only partially civilized. Elias has described how violent spontaneity in table manners, bodily functions, sexuality, and fighting gradually receded since medieval times behind a curtain of shame, transforming the very idea of proper behavior. In place of this earthy hedonism, we have been socialized in selfcontrol, becoming sensitive to the sensibilities of our fellows. The underclass seems somehow to have evaded what Elias called the civilizing process. It is not that the underclass is indifferent to shame; on the contrary, its orientation is very much toward shame (and not guilt), but shame is conceived in terms of a quasi-medieval code of honor that would redress loss of face through impulsive, ferocious retaliation -- which, 
of course, invites further retaliation. The consequences of shame, therefore, are precisely the opposite of what Elias found (see also Fletcher).

Whether pauper or drug dealer, members of the underclass pose the classic explanatory puzzle: structure or agency? Are they the playthings of larger forces too powerful and insidious to overcome, like racism (Massey and Denton) or the movement of entry-level jobs from the inner city to the suburbs (Wilson More 41)? Or are they, possessing significant autonomy to manipulate the world around them, responsible for their own plight (Mead)?

It is not hard to understand the enduring potency of the concept of the underclass. Its members serve as a tangible, cautionary example of the wages of sin, and thus give society at large a common foe to unite against. The underclass, then, like Durkheim's criminal, "plays a definite role in social life" (Durkheim 63) in unifying society against them and reaffirming its rules. In this way, paradoxically, the underclass contributes to the maintenance of social order. The underclass also carries with it a profound, legitimizing power. The deserving poor's acceptance of the system -- as manifested in their apparent commitment to hard work, their belief that individuals can rise as a result of their own efforts, their refusal to challenge the larger social and economic system, their unwillingness to complain publicly about their condition, and their obvious gratitude for aid from their betters -- helped to convince the non-poor that the society was just. After all, if losers did not seem to question the rules of the game, they must be fair enough. Moreover, by insisting on the importance of excuses to be evaluated on a case-by-case basis, the concept of the deserving poor refuted charges of heartlessness by providing opportunities for acts of sympathy and mercy. As targets of charity, the deserving poor are occasions of virtue.

It is essential to recall, however, that whatever the power of the "deserving poor" or the "underclass," these categories were constructions that helped to explain the world to those who used them, not scientific terms tied to verifiable evidence. An observer might infer gratitude from an obsequious charity case and mark him/her as "deserving," for example, but the apparent gratitude might merely be an act intended to manipulate the giver. Relatedly, since we tend to see in others what we want or expect to see and to be guided by stereotypes, we may interpret experience to match our preconceptions - and movies may be significant in this regard to the extent that they help to shape or reinforce our preconceptions. It ain't what we don't know. It's what we know that ain't so.

Not until the last half century has the simplicity of the deserving poor/underclass scenario been upset. What upset it was race. The early turn of the $20^{\text {th }}$ century underclass movies were often populated by immigrants from Eastern and Southern Europe, who were typically demarcated into races that fell awkwardly between white and black (Jacobson). It is the image of the underclass as mainly an African American phenomenon that distinguishes it from the underclass of the Depression. This newer image may probably be dated to the War on Poverty and the urban riots of the mid 1960s that exploded across the nation: in cities on the decline (like Detroit) and cities on the rise (like Los Angeles), in conservative cities (like Birmingham) and liberal cities (like New York). From 1964-1971 there were more than 750 riots, resulting in 228 deaths, 12,741 injuries, and billions of dollars in property damage -- all conveyed in headlines and bulletins, public speeches and private conversations that continued week after week, month after month, year after year. Street crime also zoomed, with murder, 
rape, and robbery rates leaping from 63.4 per 100,000 population in 1950 to 254.1 in 1975: in an increasingly affluent society there were more opportunities for crime; a breakdown of the traditional family and a general growth in permissiveness was said to have eroded the role of parents and others in authority in socializing children and regulating their behavior; and a spike in the number of teen aged males sharply increased the most crime prone segment of the population. Most of the rioters, criminals, and ne'er-do-wells depicted were African Americans (see Barlow), and as time passed, media coverage became increasingly unfriendly, mechanically referring, for example, to abuses so widespread they were routinely called "the welfare mess" (Gilens 102-32). By 1977, even the liberal Urban Institute estimated that the underclass was $70 \%$ nonwhite (F. Levy). That the scholarly and popular media appear clearly to have exaggerated the racial component in the underclass (Alex-Assensoh) is beside the point, for it was perceptions that affected policies, politics, and the movies about them.

At the same time that poverty was increasingly racialized, a steady rise in real wages, a decline in family size, and an increase in government transfer payments combined to shrink the portion of the population labeled "poor." Poverty, as a consequence, seemed easier to escape, casting more disgrace on those left behind, as well as more doubt on the bromide that poverty was the root cause of most social pathologies. Similarly, the decade 1965-1975 saw the sharpest wage gains by black men relative to white men, due mainly to the decline in legal racial discrimination (Donohue and Heckman). Yet the old maxim that a bad regime is most vulnerable, when it begins to try to reform itself may be apposite for by discarding traditions, it may generate hopes, expectations, and feelings of entitlement that will go unsatisfied, and so feed resentment, alienation, and rage. Thus, the happiness gap between the races during this period was much greater than the income gap would suggest, particularly among the young (Stevenson and Wolfers 6-7, 14-15).

21 It was in the 1960s and "70s that the "underclass" came to be contested. The right held tight to the traditional deserving poor/underclass dichotomy, with Barry Goldwater, George Wallace, Ronald Reagan, and many other prominent figures recounting narratives featuring street criminals, rioters, and welfare queens. Conservative intellectuals, meanwhile, pointed to West Indians, Asians, and other minorities, who through hard work had risen to prosperity, implicitly indicting African Americans for their failure to progress (see Sowell). Liberals, for their part, credited "white racism" (National Advisory Commission) or "poverty, inadequate housing and unemployment" (President's Commission on Law Enforcement and the Administration of Justice 6) for the underclass, their apparent refusal to blame the rioters and criminals effectively confirming for much of the public the conservatives' charge of being indulgent and naïve, confused and hapless, guilt-ridden and ineffectual. As one Democratic operative put it, "We had become a party that had stopped worrying about people who were working and only focused on people who weren't working. The party didn't understand how big a concern crime was. It had stopped talking about opportunity and growth" (Al From, quoted in Nocera).Thus, the report of the McCone Commission created by California's governor in the wake of the Watts riots was attacked for ignoring the socioeconomic roots of the violence (Governor's Commission; see Blauner 1969b).

Radicals, however, disdaining both conservatives and liberals, offered a new analysis that reconceived the deserving poor as rejecting all that yesterday's deserving poor believed (see Gitlin). The old undeserving poor who had been mocked as shiftless 
became the new deserving poor who were denied the opportunities and experiences from which motivation springs (McCord et al. 138-65; Trapp and Roberts); the old undeserving poor who had been derided as lazy became the new deserving poor who refused to be shunted off to dead-end jobs (Wellman); the old undeserving poor who had been despised as thieves and looters became the new deserving poor for whom stealing was really "a bid for the redistribution of property" by those demanding "a redefinition of property rights" (Dynes and Quarantelli). Malcolm X, Claude Brown, and Piri Thomas, among many others, were lionized, not for overcoming their underclass roots but for parading them, and thus establishing an authenticity that white radicals could only envy. The underclass thus ceased being misfits, predators, or losers and instead, relieved of sin, became members ex officio of the class of unjustly treated victims. It did not seem to have occurred to the defenders of the underclass that to be fixated on the elevated status of others is to be dominated by them.

In this, radicals followed in a long tradition of romanticizing the marginal, the exotic, and the alienated that had been reinvigorated in the 1950s in fiction, folk music, and rock ' $n$ ' roll. Unselfconsciously, Jack Kerouac had written of walking "in the Denver colored section, wishing I were a Negro, feeling that the best the white world had offered was not enough ecstasy for me, not enough life, joy, kicks, darkness, music, not enough night" (179). In a widely discussed essay, Norman Mailer similarly had announced that "in the wedding of white and black it was the Negro who brought the cultural dowry" (314). Nor was hostility to bourgeois America confined to the Right, as Ayn Rand's enormously popular Atlas Shrugged and The Fountainhead illustrate. In The Dream and the Nightmare (1993), a book lauded by President George W. Bush, a neoconservative argued that the unrestrained individualism celebrated by the $1960 \mathrm{~s}$ counterculture infected segments of the poor with a scorn for marriage and work that proved devastating (Magnet). Though critics replied that these cultural critiques neglected far more important economic and racially discriminatory factors, they were unable to dampen the interest in cultural factors. The interest in culture generally was extended to popular culture. Heretofore widely dismissed by intellectuals as lowbrow, it began to be analyzed and critiqued with a respect reserved for the classics (Horowitz), and much of what seemed authentic, creative, and emotionally powerful was produced by African Americans.

From all this, it was a short step to the conclusion that the new racialized deserving poor legitimated not the current system, but rather opposition to it -- and this new deserving poor was nothing else than the underclass (Breines; Lipsitz; Ayers). "The socalled riots," a Berkeley sociologist announced, for example, represented "a form of mass rebellion against a colonial status" (Blauner "Internal Colonialism" 398). Sermonizing the underclass about the rewards of marriage, saving for a rainy day, or an honest day's work for an honest day's pay, given these attitudes and beliefs, appeared futile and stupid. Worse, it denied the underclass its revolutionary role to instruct society on its injustices and to provide a model for resistance. No wonder the community organizer, Saul Alinsky, dismissed the liberal War on Poverty as "political pornography." Evil, in this scenario, retained its connection to antisocial conduct, but it was located not in the perpetrators but in the larger society that conditioned them to seek success but denied them legitimate means to this end (e.g., Cloward and Ohlin 106-7). Thus did a new deserving poor arise on the Left to challenge the old. 

The Eighteenth Brumaire of Louis Napoleon (Marx and Engels 295), Marx had written of the relative surplus population and the lumpenproletariat. Each was poor and outside the economic market; the relative surplus population was moral, wanted to work, and retained its class consciousness; the lumpenproletariat, on the other hand, was immoral, did not want to work, and would join with any class that would offer to buy it off. Marx sympathized with the relative surplus population (roughly, the deserving poor), but considered the lumpenproletariat (roughly, the underclass) the "scum, offal, the refuse of all classes."

But the 1960s and 1970s was an era of radical chic (Wolfe), a time when the most highly praised novelist in the nation celebrated graffiti against charges of vandalism (Mailer, Kurlansky, and Naar), and the most highly praised political philosopher posited the condition of the least well off -- not the overall level of liberty, opportunity, virtue, prosperity, security, or democracy -- as the sole indispensable measure of social justice (Rawls). Meanwhile, the old deserving poor, now revealed as ignorant dupes, were hardly worth discussing, except to note that their docility served the interests of their oppressors (Piven and Cloward).

By the 1980s, the radical critique had dwindled to a faint diminuendo, and liberalism, assaulted and in disarray, had for much of the country become a term of abuse. The politicization of cultural matters, pursued by both the Left and the Right in the 1960s, was now pursued almost entirely by the Right, as the Moral Majority and other evangelical groups became major electoral and issue forces. It was in this context that the urban underclass became a national preoccupation (Muzzio "Smell," "Urban Basement"). In addition to the familiar welfare screeds, respected journalists produced widely discussed works on the topic (see Auletta; Lemann); Bill Moyers generated controversy with a two-hour CBS documentary, Crisis in Black America, featuring one well-named Timothy McSeed, an unemployed father of six children by four women; academics agreed that the underclass phenomenon was qualitatively and quantitatively unprecedented (Wilson "Truly Disadvantaged"; Nathan; Lowenstein); and a 1980 Miami riot, which left eighteen dead and hundreds severely injured, provided a booming echo of the bad old days of the " 60 s. A best-seller by a little known social scientist, Charles Murray, entitled Losing Ground (1984), denounced government welfare programs less for the traditional reason that they were wasteful than for a newer reason (that echoed America's first social welfare textbook [Warner]) that would energize conservatives for years to come. By creating perverse incentives, Murray claimed, the programs were hurting the poor and transforming them into the underclass; ridding the poor of programs intended to help them would help them to help themselves. Other writers echoed this call, sometimes arguing that the answer was spiritual (see Olasky). By the end of the Reagan era, the underclass had become a scandal du jour, or, to be more precise, a moral panic.

In Folk Devils and Moral Panics, Cohen speaks of these panics as involving a group "defined as a threat to societal values and interests; its nature is presented in a stylized and stereotypical fashion by the mass media," and subsequently validated by public figures and "socially accredited experts" (9). Fears and fantasies brought on by the anxiety of social change are amplified by the media and other moral entrepreneurs, who scapegoat the moral deviants as folk devils. Cohen seems to believe that panics begin with the media, with their bottomless appetite for the spectacular, the violent, 
the Other; Goode and Ben-Yehuda contend that the panics are "deliberately and consciously" engineered by elites to distract the public from more serious concerns; and Lea and Young argue that moral panics grow out of the public's real experience with the problem. Apart from Lea and Young's grass roots approach, none of these writers, it must be said, is very careful in establishing that what panicked the media equally panicked the populace.

The attention directed at the underclass, in any case, generated considerable ambivalence in white society. Exploding street crime and the trauma of the urban riots of the 1960s and 1970s had marked the African American underclass as enraged, explosively violent, unimaginably threatening. "We a BaddDD People," announced a Black Power era poet (Sanchez). Yet the profound and undeniable facts of slavery, segregation, and discrimination also meant that this feared class possessed an immense moral advantage, and could not simply be answered with condemnation. Inarguably, they had been treated unjustly and shamefully.

\section{Scene II: Doing the Right Thing by the Boyz $\mathrm{N}$ the Hood}

30 From the perspective of Hollywood, what is perhaps most interesting is what did not happen. Urban riots, with their action, violence, and potential for powerful narratives, generated no studio productions. Notwithstanding its potential for narratives of uplift and corruption, dramatic and comedic, welfare was rarely in evidence. That these and related topics were at the time so widely discussed would seem to have guaranteed substantial audiences. Yet Hollywood's involvement in the so-called "plight of the cities" remained modest. In time, however, once the threat of the urban underclass receded, it could appear more fascinating than dangerous, and regain its place as an important Hollywood genre.

31 In the 1960s, 1970s, and 1980s, Hollywood paid little attention to the urban underclass, perhaps siting it in a stylized musical (West Side Story, 1961) or the Big City as seen by a newly arrived country boy (Midnight Cowboy, 1969), off in the future (Escape from New York, 1981), or in a handful of independent films that never reached a general audience (The Connection, 1962; The Cool World, 1963). Of the few films set in the present, Martin Scorsese's Mean Streets (1973), a claustrophobic study of young toughs in Manhattan's Little Italy, won the most critical praise. It was The Warriors (1979), however, that has continued to generate the greatest interest. Based on Xenophon's ancient narrative, Anabasis, of 10,000 Greek soldiers fighting their way home from war, it traces the return of a gang from the Bronx to Coney Island, mostly via an extraordinary subway system radiating garishness, gloom, and menace. The characters, however, are entirely cartoonish, and so the question of what formed them never arises; their underclass status is simply a given. Notwithstanding The Warriors, however, the commercial potential of the new deserving poor largely escaped Hollywood's notice, much as New York filmmakers had at first failed to see the potential of films about the poor threequarters of a century earlier.

32 African American filmmakers, however, saw the potential very clearly. Traditionally, Hollywood had reproduced popularized "black stereotypes that had existed since the days of slavery" (Bogle 4), nearly always as minor characters. Movies targeted at African American audiences had often urged blacks to imitate white customs and manners; these movies were typically produced by white-owned companies and shown 
at white-owned theatres. Both the most famous silent film, Birth of a Nation (1915), and the first major talkie, The Jazz Singer (1927), featured white men in black face. General audience movies with black casts had tended to be heavily stereotypical (Green Pasture, 1936; Cabin in the Sky, 1943), and "northern urban [African American ] life was ignored" (Silk and Silk 145).

That these days were over was made irrefutably clear in Melvin Van Peebles' Sweet Sweetback's Baadassss Song (1971), a fast-paced tale of an angry super stud's flight from the police and the "first [movie] to glorify the pimp" (Bogle 2). At the close of Sweetback, the screen proclaimed, "A baadassss nigger is coming back to collect some dues," and with this established a niche of low-budget "blaxploitation" movies. The Shaft series (Shaft, 1971; Shaft's Big Score, 1972; and Shaft in Africa, 1973), concerning "a black private dick who's a sex machine to all the chicks," was the best known of these. Also notable were Pam Grier's Amazonian Coffy (1973), Foxy Brown (1974), and Sheba, Baby (1975), as well as Superfly (1972), Cleopatra Jones (1973), and Get Christy Love (1974). At the same time, in dissonant counterpoint, white audiences were flocking to Dirty Harry (1971) and Death Wish (1974) - plus their numerous sequels - where dehumanized urban, often black criminals came to experience justice through extravagantly extrajudicial means.

The blaxploitation language and themes that appear so unexceptional today seemed to the 1970s audiences radically new. It was not that viewers were unfamiliar with all this; rather, they had never seen it so vividly and aggressively displayed in movies. Perhaps it was in recognition of this that one scholar has spoken of blaxploitation films as a "complex body of work" featuring "multidimensional characters [in] their full humanity" (Guerrero 69-70), though the movies' narratives in truth were as nuanced as playground graffiti. Because they brazenly celebrated conventionally anti-social behavior, they came under feeble attack from members of the African American establishment (see Griffin). In any case, by the mid-1970s, the brief blaxploitation vogue was over, and Hollywood seems to have concluded that the subject of the urban African American underclass was exhausted.

That this was false had to be demonstrated by an outsider, Spike Lee, and his immensely ambitious Do the Right Thing (1989), "the most controversial film of the year" (Ebert 167). On the cover of Newsweek, interviewed on television and in magazines, Lee was immediately established as a black wunderkind, articulate, outrageous, smart, charismatic, and angry.

In Do the Right Thing, on the very hottest day of the summer the class prejudices and conflicting racial allegiances of generally symbiotic neighbors on one street in BedfordStuyvesant, Brooklyn, inexorably lead to the killing of an African American man by the police and the torching of Sal's Famous Pizzeria by rampaging blacks. In focusing on one street on one day, Lee revisited the synecdoche of a microcosm employed in classic New York movies of an earlier era, specifically, Street Scene (1931) and Dead End (1937).

37 Lee's street is predominantly African American, seasoned with Puerto Rican stoop sitters, a yuppie WASP brownstone owner, an Italian-American pizzeria proprietor ("these people have grown up on my pizza") and his two sons, and a shopkeeping Korean couple, all of whom are shown as the camera follows Lee's friendly character as he ambles along. These "different ethnic groups," according to Lee, "reflect the city as a whole" (qtd. in Emery 145). The film owes its great strength to the ambivalence of the characters' relations with each other. Lee does not pretend that all these people are 
alike under their different colored skins. Nor does he paint them as so many good guys and bad guys. Instead, his characters, like real human beings, are marked by a jumble of feelings and beliefs. They know each other, accept each other's differences, and experience a sense of community. Yet they are also suspicious of each other and often governed by hostile stereotypes, as the film's brilliant, profane montage of competing ethnic slanders highlights.

Lee's neighborhood may resemble a small town, where, as one small town mayor observed, "Maybe nice is what you have to be or you'd be swinging at each other all the time" (qtd. in Davis 17). But Lee's people are not small town nice, and do swing at each other. Thus, Lee's character (heretofore entirely without menace) at the peak of the rioting tosses a garbage can through the pizzeria's window. Though he retains a fondness for the pizzeria owner for whom he worked, his heart lies with the black rebellion. The other African American characters reveal no such conflicted emotions, laying aside their differences in order to unite in violence against the whites. Racial categorization, which had favored whites, now punishes them. Doing the right thing, the film seems to conclude, entails overcoming inhibitions and joining in acts of racial solidarity, even if they are violent - at least if you are among the oppressed.

Lee contended that his film explored the "black underclass," who live "in the bowels of the socioeconomic system" (Lee 109). Yet to what extent the movie's ghetto is truly an underclass locale may be open to question, for it is not devastated by poverty, unemployment, or drug abuse, but oddly echoes the shtetl of Fiddler on the Roof (1971). The street is more a social center, lively and interesting, than a locus for urban pathology. The movie's enormous success, in any case, opened the door for other young African American directors, and they, more than Lee, focused on underclass narratives of criminals, addicts, and unwed mothers in an environment where crime, drugs, joblessness, welfare dependency, and indiscriminate violence are the realities of daily life. In all this could be heard the echo of the blaxploitation movies of years earlier, but these new films were far more ambitious in purpose and serious in execution.

What could also be heard, though in bowdlerized versions, was the radical critique of a generation earlier. The underclass, again emblematic of society's fundamental injustice, is the new deserving poor. Its members may do bad things, it is true, but the real culprit is society, racist, unequal, and unfair. Underclass behavior, therefore, is not merely excused; it is praised, for there is something heroic about it. Yet the films draw back from the last step of the radical critique, the call for revolution. Events had revealed this to be childish and futile.

41 The cynicism behind this critique had an easy logic: irrespective of its rhetoric, government could not be trusted to help those in need because it was controlled by their enemies: those with power and money. Countless everyday encounters with police and bureaucrats were taken to underscore the irrefutable fact of their hostility or indifference. Even anti-poverty programs, often seen as stingy, demeaning, and intrusive, could not escape attack (though even when they fail to reduce poverty, they may improve physical and mental health and subjective well-being [Ludwig et al.]). Other programs with fine sounding rationales, like zoning or building codes, also had perverse effects, for example, discouraging residential construction, and thereby raising rents, exacerbating crowding, and limiting good paying jobs.

These ghetto gangster films of the 1990s were made by African American directors for African American audiences and white crossover audiences, and reflected the 
prominence of African American moviegoers. African Americans comprised 25-30\% of the national audience, and in a time of declining industry profits, seemed more important than ever; black movies, lacking top-tier stars and directors and requiring little in the way of special effects or marketing, were low-cost products; and ancillary money making opportunities -- soundtracks, video rentals, and so on -- were unusually promising. But if the industry was thinking chiefly in terms of economics, the directors had a larger goal in mind. They had African American stories to tell to a world that they believed had heard far too few of them. Which emphatically is not to say that the point was to educate whites, but rather to present the African American experience to any who would come to view it.

Boyz N the Hood (1991), Straight Out of Brooklyn (1991), Hangin' with the Homeboys (1991), South Central (1992), Menace II Society (1993), Juice (1993), and Clockers (1995) exemplify this genre, coarse and yet evocative portrayals of an African American urban underclass struggling to achieve respect and material comforts by a variety of means, legal and illegal. Where a quarter century earlier, civil rights organizations had pressured Hollywood to abandon its black stereotypes in favor of middle class portrayals -- Sidney Poitier had rejected the role of Porgy in Porgy and Bess because he thought it "not material complimentary to black people" (205) -- these movies took a decidedly different tack, "exoticizing the ghetto and its residents" (Wacquaint 35). Collectively, the films comprised nothing less than an homage to the underclass. Though its members might fight among themselves, they constituted a true community of the spirit, a community brought together by a common foe: voracious, vicious, hypocritical, mindless, evil racism. Other slum residents, unable to see through the innumerable misleading messages from the media, advertising, public officials, and schools, might succumb to false consciousness. But the movies' underclass, echoing the views of radicals of an earlier day, features characters who grasp the fact of systemic oppression and exploitation, having learned this lesson not from books but from life. As a consequence, they are not mere hoodlums or criminals. Their crimes, while not political crimes like criticizing a tyrant, are not conventional crimes against persons and property, either, nor even, as one sociologist put it, "a distorted form of social protest" (Karmen). Instead, their words and deeds must be seen as part of a struggle to right wrongs as much as to enrich themselves. The underclass are soldiers in a race war, activists in a social movement.

The movies' African American underclass occupies a specific terrain, the ghetto. In the abstract, it is not obvious that the effects of ghettoization need be harmful. Separatists have argued that, under the proper circumstances, it can enhance feelings of power, solidarity, and pride, and conduce to ideological thinking, cooperation, and self-help (see Tyner). If the ghetto includes persons of different strata, this heterogeneity may provide role models, stoke ambition, and offer a variety of goods and services otherwise unobtainable. The insider-outsider dichotomy may also shield vulnerable entrepreneurs from potentially devastating outside competition (Glazer and Moynihan; Wilson "Truly Disadvantaged"). Real life problems, however, intrude to overcome these apparent advantages: ghettos physically separate residents from middle class society, from good jobs, and from quality public services, heightening destructive peer pressures and nasty stereotypes. For these and other reasons, ghettoization leaves its residents seriously worse off (Cutler and Glaeser). 

the sense of belonging) and the costs (e.g. violence, poverty, despair) of ghetto life. Directed by twenty-three year old John Singleton, the film begins in South Central Los Angeles, circa 1984, and follows the story of three friends, who grow from boyhood to manhood on the same street, surrounded by the same people. The three principal boyz represent three paths for young African American men in the ghetto: Doughboy, gangbanging, dope dealing, boasting and bragging, rejects the unattainable status of the white middle class world; his half brother Ricky, married and an athlete, studies to win a college scholarship that he sees as his route of escape; and Tre and his girlfriend (like DuBois' "talented tenth") pursue achievement in the framework of a stable relationship, going on (like Spike Lee) to Morehouse College. However different the paths, each rests on an individualistic notion of self-help. Doughboy and Ricky are doomed: their surroundings will overwhelm and defeat them. It is only the how and why that are problematic. Will a trifling slight provoke a murderous response? Will an accident prove fatal? Tre, torn between loyalty to his friends and ambition to escape, flees the ghetto and survives. His two pals, both bright enough to prosper in more fortunate circumstances, do not make it. Doughboy, struggling to place the blame at the close of the film, laments, "Either they don't know, or they don't show, or don't care about what's going on in the "hood." still, there is something admirable and stirring about the boyz' struggle. The movie closes with a command/plea: "Increase the Peace." Its first week in Los Angeles saw thirty-three wounded and one killed in connection with its showing.

Menace II Society, filmed in the Jordan Downs housing project in Watts, immediately establishes its bona fides with archival footage of the famed 1964 riots. One of itsmain characters, obsessed with respect, kills a Korean shopkeeper who made the mistake of commenting on his mother, and then (for good measure) kills the shopkeeper's wife, as well. Although he lives by intimidation, the killer is so bereft of inner resources that avoiding shame and punishing those who shame him consume his life. The other protagonist sees his parents' lives ruined by drugs, leaving him orphaned as a teenager. Events proceed with inevitability. Yet if both main characters are murderers, they are also above all victims of the ubiquitous temptations that lead them to their destruction. "I don't think God cares too much about us," complains one of the killers, "or he wouldn't have put us here." The film neither condemns the underclass nor inquires as to why their painful experiences did not lead the protagonists to flee the life of violence, drugs, and macho bravado. Instead, in a sympathetic fashion it urges the viewer to understand them on their own terms. As a mature adult character instructs the youths, "Being a black man in America isn't easy. The hunt is on, and you're the prey. All I'm saying is . . all I'm saying is . . Survive!" Which is not to say that he believes mere survival is enough; he does not require scholarly papers to understand that childhood stress is associated with later physical and mental health problems (Wegman and Stetler; Nani, Usher, and Albanese) nor would he be surprised to learn that it might even change one's DNA (Shalev, Moffitt, and Avshalom; Drury et al.).

Implicit in the film is Jane Jacobs' well-known condemnation of tower-in-the-park projects as soulless, dehumanizing and dull, sterile substitutes for the stable and nurturing neighborhoods they replaced. Certainly, the projects' monotonous, unadorned blank faces form a grim counter to the lively streetscape of Do the Right Thing that overflowed with ornamentation, variation, and vitality. Indeed, the

European journal of American studies, 8-1 | 2013 
tenements, denounced in ' 30 s films as sources of underclass pathology, by contrast look positively warm and inviting, their eyes on the street working as reassuring guardians.

Set It Off (1996), in one sense a standard underclass movie with its car chases, explosions, and profanity, is notable for a pair of major departures. First, in a stunning departure from the proverbially misogynistic ghettocentric narrative, the main characters (echoing Blondie Johnson, 1933) are women, four African American life-long friends. Second, the economic structural emphasis almost completely obliterates the culture of poverty, as the movie stresses that their desperation for money derives from their accurate belief that the system unfairly denies them their due. "The only way we gonna get cash," one says, "is if we take a bank," and so they rob a bank and, exhilarated by the experience, rob two more. The feminist challenge to take control of their own lives and renounce victimhood leads the women to violent crime. It is the manifest injustice of the system that goads them on, not mere greed, and in the film's eyes transforms them into heroines.

In a very different way, the system is assailed in Gridlock'd (1997), a semi-humorous tale of two bantering buddies, one African American and the other white, and their efforts to game the Detroit welfare system, so they can kick their drug addiction. As clever as they are, they are no match for the complex stupidity, or stupid complexity, of the welfare system, which is relentless in thwarting their attempts to do the right thing. The environment is blamed not for making them underclass but for foiling their efforts at escape. Still more hostile to the Establishment was Belly (1998), which focused on a gangbanger who, eventually captured by federal agents, is forced to choose between a life sentence or planting drugs on and murdering the good Reverend Savior on New Year's Eve.

In all these films, the reel city of the African American underclass movies is Long's well known Indian reservation of the poor, the deviant, the unwanted, and of those who make a career of managing them for the rest of society (Long; see Shefter on the images of inner cities as internal colonies). A note of irony is supplied when in Boyz $N$ the Hood and Menace II Society long helicopter shots of the urban wasteland depict Los Angeles, the palm tree and celebrity Promised Land for America's whites, a place offering "the highest possible life ... for ordinary people" (Starr). The whites' paradise is revealed as a crime ridden holding tank for an African American underclass ensnared by racism and poverty, driven by rage and despair.

51 That Los Angeles is a holding tank for Latinos is a theme taken up by American Me (1992), a Latin gangster film. Montoya Santana, conceived when a Marine raped a Mexican woman during the infamous Zoot Suit riots in 1943, thrives in the gangs of East Los Angeles but is sent to prison. The prison scenes, shot in Folsom with inmates as extras, are powerful and graphic: multiple rapes plus beatings, drug smuggling, and much else, all conducted in a sealed-off society governed by predators; those ostensibly in charge, the prison authorities, seem to give tacit consent to the arrangement.

Santana's time there begins brutally, as he is raped and then kills the rapist, but while still a prisoner, he becomes a major player in the southern California drug trade, and tightens his grip when he is released. As a free man, however, Santana starts to have second thoughts about the corrosive effects of his drugs on the Latin American community, and finds a sweet girlfriend. All this leaves him too soft to maintain total domination of his gang, and his violent thirty-year odyssey comes to an abrupt end. In a final speech, Santana delivers the film's ambivalent message: "a long time ago, two 
best homeboys, two kids were thrown into juvie ... and they did what they had to do ... to gain respect for their people, to show the world that no one could take their class from them. No one had to take it from us. Whatever we had, we gave it away." Santana's environment made him a gangster, forcing him to do what he had to do. At the same time, the choice -- to pursue honor and respect through beatings, murders, and drug selling -- was his, and the consequences for him and those he touched were disastrous.

53 By this time, ghettocentric movies had become, among other things, lessons in conspicuous consumption, where property is the essential marker of status, and the more wasteful and extravagant the display, the higher the status. That these consumers are positioned among the underclass and not, as in Veblen's model, at the peak of the social hierarchy does not deny them this role (see Fine; Lears). What they possess in abundance is what Bourdieu called cultural capital, an accumulated stock of knowledge and experience that sets their taste and conduct apart and renders it worthy of emulation. Where Bourdieu emphasized the importance of the cultural capital of the bourgeoisie, the films take exactly the opposite view. Thus has the function of class been turned on its head.

\section{Scene III: The Next Stage}

The ghetto films, with their themes of rebellion, and alienation conveyed in a relentless rat-a-tat of violence, sex, and profanity, had obvious appeal for teenaged males. And just as hip-hop exploded beyond its original African American constituency, urban underclass movies featuring different ethnicities have proliferated. Notwithstanding the cultural segregation of the races -- whites and blacks do not watch the same television programs, read the same books, even smoke the same cigarettes or drink the same liquor -- white youths felt drawn to the black underclass, at least in abstracto. In this, the white youths sounded a bizarre echo of Walter Benjamin's flâneurs,remaining for the most part mere observers of the passing scene, or more precisely, the scene as reconstituted in movies, music, and video games. Yet unlike the flâneurs, the white youths are not disinterested, but rather join in emulating the surface tics that in their eyes identify the underclass. Jailhouse chic becomes a fashion (Trebay), shirts blasted with shotguns and pistols sell for $\$ 100$ (Koerner), tours of "high-profile gang areas of Los Angeles were nearly sold out" (Archibold; see Whyte, Selinger, and Outterso), and young white authors pretend to a gangland (Jones) or otherwise underclass (LeRoy) youth.

Even this emulation, however, took a while for filmmakers to notice. Thus, the most prominent of the new wave of depictions of the white underclass, Kids (1995), centered on adolescents very different from those in the films of African American directors. Neither victims of racism nor its enemies, these white youths seem entirely unmoored from all considerations of social justice. Relatedly, they are also unmoored from the larger society, and almost entirely anomic. Where African American underclass films present characters embedded (for better or worse) in powerful community contexts, Kids' teenagers are free floating and without societal roots. Their alienation is existential, rather than a consequence of such social forces as the Great Depression or racial discrimination. The result is a film eerily resembling a documentary on animals in the wild. The boys, who dominate the film, are predators. Among themselves they 
are full of high-spirited camaraderie, but they imagine that the rest of the world, to the extent that they are conscious of its existence, is there simply to provide victims: after a trifling encounter a man is beaten, perhaps to death, for the sheer fun of it; a cat is kicked; above all, girls are used and abused. The leading character ("the virgin surgeon"), who carries the AIDS virus, is obsessed with deflowering very young virgins; his best buddy rapes a girl in a drugged stupor; a friend of theirs seduces a developmentally disabled girl with leg braces. If the boys are the wolves, the girls are the fawns: vulnerable, passive, so witless that they succumb to tired pick-up lines poorly delivered. All of them, preoccupied with sex, booze, and pot, live entirely for the moment; it is impossible to imagine them as middle-aged. Parents, apart from a brief scene featuring a slovenly, indecisive mother, make no appearance at all. Kids lacks the signature car chases and explosions that mark the black films and does not attempt to explain its underclass in terms of structure or agency. Rather, it purports only to record. Later independent films on the white underclass, on the other hand, tended to view them as objects of pity, living lives of humiliation and defeat (Bobby G. Can't Swim, 2002; Virgil Bliss, 2002). Unable to attribute their failure to racism, they must carry the burden themselves. But if they are not celebrated, they are really not blamed, either. Like the poor and working class whites discussed a few years later by Murray, notorious for earlier books on African Americans, they seem increasingly losing touch with the "founding virtues" of industriousness, honesty, marriage, and religion that he believes were largely responsible for the success of the nation.

The most bizarre film in this mini-genre probably is Whiteboys (1999), whose central character is a white teenager in rural Iowa, who "still got the ghetto in my heart." He walks and talks like an urban rapper, dreams of appearing on Jay Leno and explaining that "this rare skin disorder" makes him look white though he is actually black, and fantasizes about drug dealing in Chicago's notorious Cabrini Green housing project. The Cabrini fantasy comes true, and he encounters reality in the form of robbery and a beating (on the wigger phenomenon, see Bucholtz). Spring Breakers (2012), in a variation on this theme, follows prototypical pretty white college girls, who, bored with their lives, rob a convenience store, shack up with a drug dealer in Florida, and wielding automatic weapons mow down a dozen or so of his rivals - after which they cheerfully drive home.

By the late 1990s, the underclass genre mutated, as a more hopeful theme arose to contest the preoccupation with pervasive, immovable injustice. The key film was 8 Mile (2002), a star vehicle for Eminem as Rabbit, which grossed $\$ 54,000,000$ on its opening weekend. The title refers to 8 Mile Road, which separates Detroit from suburban, largely white Oakland County. The film has several themes -- for example, Rabbit's relationship with his darling little sister and whorish mother -- but mostly it is a retelling of the American Dream. Driven by his love for rap and his need to create a fit life to live, Rabbit overcomes his own fears and the blacks' sense that rap is their music to win their acclaim in a final gladiatorial contest. The American Dream, of course, is about class, and 8 Mile makes it clear that class trumps all, even race. Though Rabbit's black foes derisively call him Elvis, he triumphs when in the showdown he discloses in a Nixonian ambush that his African American rival had attended a suburban private school. ${ }^{3}$ In an oddly old fashioned way, the movie seems intended to be inspirational: hard work, commitment, talent, in short, merit will lead even underdogs to success; privilege quite properly generates envy, which may undo privilege. 

his talent (or his innate humanity) enables him to use this underclass experience to produce something that the world will see as of genuine value; the system is sufficiently meritocratic to provide him, after some scuffling, with an opportunity to succeed; and in the end he triumphs not by denying what he is but by using it to become someone better. For rap, though the soundtrack of the underclass, has vast appeal in society generally.

The optimism, however, is dampened by a number of factors. There is, above all, the setting. Detroit is unrelievedly ugly: decaying, filthy, dark, dangerous. If the inhabitants have created a few islands of fun, like the nightclub where the rappers combat, it remains a place where no one would choose to live. Further, Rabbit with his cold stare, petulance, and readiness to fight, does not reveal much warmth. Though his crew, with its ritual greetings and joshings, is full of affection, Rabbit keeps his distance, and in the closing shot walks away alone, retaining his day job as a metal presser at an auto factory. This downbeat ending adds immeasurably to the movie's credibility. And rap -- unlike, say, the Cole Porter confections of another era -- rises or falls on its credibility.

This credibility is not always deserved. Rappers often exaggerate or even fabricate a criminal past. Nor is the authenticity of the underclass itself beyond challenge, for its rigidly enforced slang, greetings, clothing, and even handshakes bespeak a pervasive conformity that may conceal the real person beneath impenetrable layers of ritual. Meanwhile, middle class adults are likely to regard authenticity as hopelessly passé, having detoured to the more complicated path of irony.

African American underclass movies continued to appear, usually with faster car chases produced by John Singleton. DJay, a small-time Memphis pimp and pot dealer, dreams of success as a rap singer. Unaccountably, he experiences a tearful epiphany at a gospel music recording session, and commits to giving up pimping to pursue rap stardom, which he does with a little help from his friends and his former employees. $\mathrm{He}$ convinces a skeptical local rapper who has made good to listen, and soon he is on his way. Hip-hop is the perfect path to advancement, for its coded language, full of slang, profanity, obscure references, and puns, defies understanding by the uninitiated but is the lingua franca of those in the know. Its insider nature means that DJ's rise implicitly endorses the cultural milieu that gave it birth.

What drives the story is uplift: circumstances force a talented man into the underclass; DJay's rise (like Eminem's in 8 Mile) is radically different from the earlier underclass movies. In those films, the underclass provided soldiers for violent warfare against an oppressive system. Overmatched, the soldiers' fate is sealed, and it is this tragedy that completes the romantic arc of their heroism. Hustle and Flow and 8 Mile, on the other hand, though not lacking in the dismal and the sordid, highlight well-earned success. Membership in the underclass may be environmentally caused but it can be overcome by individual moral effort. Far from being a life sentence to hell, such membership may in the right hands be a ticket to glory. In their commitment to the conventional American formula of success as a function of individual talent and effort, both of these films depart from the movies' conventional treatment of the underclass. For a dominant theme in hip-hop has always been the worshipping of personal, material success. Youngsters fantasize about rapping their way to fame and fortune as earlier 
generations might have mused on the payoff from sports, and stars like Diddy and Jay Z are idolized perhaps more as entrepreneurs than as performers.

That the older veneration of the underclass was far from dead was made clear in the vastly popular American Gangster (2007), which, as a kind of African American Godfather, traces the rise and fall of Frank Lucas, a real-life Harlem drug kingpin. Frank becomes enormously wealthy and powerful, besting the Mafia and, for a time, outwitting the FBI. In a classic robber-baron entrepreneurial fashion, he eliminates the middleman, undercuts the competition, and maximizes his market share, all the while leveraging his blackness, which earns him adulation in Harlem at the same time that it induces the racist police repeatedly to underestimate him. Unlike the underclass youths in earlier films, Frank is calculating, detached, a master of tactics, his affluence proclaimed by his dapper appearance that owes nothing to the lower classes. What is unsettling is that Frank is offered as a kind of criminal Jackie Robinson, the first of his race to dominate the rackets, a path breaker, a role model, an inspiration, complete with maxims like "Either you're somebody or you ain't nobody." Though the movie occasionally alludes to the black lives ruined by Frank's drugs, it remains so bedazzled by his charisma that we almost expect to see him inducted into a Bad Guys Hall of Fame. In the end, like the gangsters of an earlier day (Little Caesar, 1931; Scarface, 1932), Frank overreaches, his pride bringing about his destruction. Yet when he is sent to prison, we are left bewildered and let down. DJay and Frank are radically different entrepreneurs.

If Frank represented a black version of a white prototype, the same could hardly be said about the Notorious B.I.G. (aka Biggie Smalls, né Christopher Wallace), the hero of a semi-authorized film biography of the African American rapper, Notorious (2009). Biggie, in addition to rapping, deals crack, abuses women, and is a master of intimidation, physical and psychological. His murder at age twenty-four is not surprising. Biggie is a proud black man, a hip-hop antihero, an outsider speaking truth to power in a vernacular that makes no concessions to polite white sensibilities. Yet his appearance, a pinstriped suit and a homburg hat, playfully echoes that of white moguls of another time, and his earnings seem more likely to go to conspicuous consumption than to aiding his underprivileged followers. He is smart and brave but he is also selfish and cruel. Yet what saves him from serving as a role model are not his sins, but merely his early death. The movie's release coincided with the inauguration of Barack Obama, a polar opposite -- a law-abiding family man, the embodiment of self-control and sweet reason, a voice pleading for sacrifice for the common good. The movie earned $\$ 24$ million on its first weekend, perhaps drawing some of its audience from Obama's euphoric supporters. The attraction of the underclass remains alive and well.

By this time, the growing rejection of the Bush administration and its conservative policies had reignited the venerable structure versus agency controversy. Reinvigorated liberals highlighted such endogenous factors as inadequate schools (Orfield) and defective child support policies (Mincy), reasoning that if the causes of urban poverty and the underclass were political and economic, the cure must lie in appropriate political and economic policies. Still, conservative observers continued to emphasize agency, particularly, in a widely quoted op-ed by the African American Harvard sociologist, Orlando Patterson. He damned a "cool-pose culture" that generated powerful self-esteem through a masculine stance of invulnerability and a "Dionysian trap [of] shopping and dressing sharply, sexual conquests, party drugs, hip hop music and culture . . . which feeds their pride." Underclass movies, from 
Patterson's perspective, appear as both a cause and effect of a poisonous lifestyle -- and a significant part of the problem.

It is the tension between structure and agency that drives the extraordinary Precious: Based on the Novel Push by Sapphire (2009). The misnamed Precious -- no one considers her precious, not even herself -- confronts us like no other star. Immensely obese, she is to the other characters a grotesque thing. We quickly learn of the wretched state of her life: at sixteen she is pregnant for the second time (and HIV positive) from a rape by her father; her toddler (whom she calls "Mongo" for mongoloid) has Down syndrome; she is depressed to the point of near muteness; and she is illiterate.

Precious is immersed in a culture of poverty manifested as an enraged defeatism that mocks and dismisses all efforts at self-improvement, and at first she is simply a sad study in self-pity and dreamy fantasizing. Her sadistic mother, who at one point targets her with a thrown television, treats her as a slave; neighborhood toughs humiliate her, literally pushing her around; abuse evokes from her little more than stone faced silence.

But gradually, placed in a new all-female school, she opens up as she encounters encouraging adults and peers. By the movie's end, she wins a literary prize, leaves her monstrous mother, and begins the task of remaking her life. No longer grotesque or a thing, she is a formidable woman. Her triumph, the film makes clear, is less over prejudice against race, gender, and weight and more over the habits of thinking and feeling that she had internalized as a consequence of the insidious culture of poverty that had very nearly wrecked her life, as it had wrecked the lives of so many around her. The movie's director, Lee Daniels, declared that his "message" was "My world is dark, but the light is coming on" (qtd. in Hirschber 68), and Precious' rescue from a life of unremitting horror is undeniably a cause for rejoicing.

This optimism, however, is rebutted by the otherwise overwhelming power of the reinforcing pathologies that doom nearly everyone else. Even her evil mother, it develops, is as much a victim as a victimizer. If the salvation of these damaged individuals depends upon their meeting up with the kinds of people who aided Precious, their prospects are surely bleak, for there have never been enough gifted helping hands to go around. Precious, therefore, is really not a social problem movie, certainly not in the 1930s tradition, but rather the story of one person's difficult and unlikely journey to self-realization. Superficially, it may seem a modern variation on the old tale of the ugly duckling, but in that famous story the key agent of change was simply biological maturation. In Precious, on the other hand, though structural forces, racism, and the culture of poverty are terrible obstacles, agency in the form of human effort and determination overcomes these hurdles.

In an unexpected way, these later, more buoyant films speak to the tension between liberty and equality. Tocqueville had argued that Americans would prefer equality to liberty. Liberty was useful chiefly to dissidents, he thought, of whom there would never be many; equality, on the other hand, whether of condition or opportunity, would be valued by ordinary people; moreover, where freedom's promise might seem speculative, abstract, and remote, equality offered tangible benefits here and now. Yet the ghettocentric films' interest is entirely in liberty. It is the striving of the protagonists that is celebrated. Those left behind are ignored. Further, the liberty that is venerated is economic liberty, really the liberty to compete in the marketplace. And this liberty, so alien to the early ghettocentric films, also entails reliance on such classic 
bourgeois norms as hard work and trusting strangers. In this, they reflect an American tradition, in which the moral logic of risk taking was central (J. Levy).

What is missing, oddly, is a focus on increasing socioeconomic inequality and decreasing socioeconomic mobility. Horatio Alger's tales of rags to riches (1868/1926; 1869) and James Truslow Adams' American Dream - these clichés may have retained some popular authority, but scholars had demonstrated that the ongoing real world trajectory was in the opposite direction, especially for men and especially for African Americans (Isaacs; Pew). Moviemakers did not feed off academics.

Fruitvale Station (2013), a critically acclaimed film based on a real world killing, departs from previous models. Its hero, Oscar, an ex-convict, is a marijuana dealer, and so irresponsible that he loses a regular job he desperately needs due to lateness and cheats on the girlfriend whom he loves and is the mother of his only child whom he adores. But he is also charming, generous, utterly devoted to his daughter, in short, a complicated man easily distracted by temptation but with a good heart. He meets disaster, however, not because of his weaknesses, but simply due to racism: an Aryan Nation type he knew in prison starts a fight with him on a train his crew had taken to view New Year's Eve fireworks, and a bigoted brute of a policeman fatally shoots him in the back while he lies facedown on a train station platform.

The movie rejoices in the free-spirited fun of the underclass life, but understands that its short-term exhilaration is purchased with prison time, unemployment, the humiliation that comes when a macho man is unable to provide for his family, and the real possibility of early, violent death. At the same time, though, Fruitvale makes it plain that it was not the underclass life that doomed Oscar, except for the random encounter with the racist ex-con. Indeed, it is easy to imagine that his end might have befallen any young black male, who found himself in the wrong place at the wrong time.

\section{Coda}

74 "Practical men, who believe themselves to be quite exempt from any intellectual influences are usually the slaves of some defunct economist," observed Keynes (383). He might well have added "defunct social theorist," since for generations the film maker's fascination with the underclass has remained hinged to the old culture of poverty model, which explains the social pathology of the underclass as coping mechanisms that arose in response to the wider (and well disguised) social pathologies of American life generally. This venerable approach has continued to drive nearly all urban underclass film narratives, perhaps because it focuses more on the criminal than on the crime, more on apprehension and punishment than on prevention, more on daring-do than on managerial tinkering.

In the past, when much of America was poor, movies made poverty a standard theme. The deserving poor were singled out for special praise, but even the dangerous underclass was typically excused by an environmental determinism that relieved its members of responsibility for their situation, if not always for their behavior. Meanwhile, middle class journalists, clergy, reformers, and social critics wrote of the deserving poor and the underclass. The deserving poor, blameless victims, affirmed the competitive, materialistic, individualistic values of their betters, and consequently were entitled to aid. The underclass, indolent, immoral rogues rejected the dominant values and were consequently entitled to little or nothing. 
76 After the Depression, prosperity nibbled away at the poor, who for years seemed almost to have vanished from the movie screen. A wealthier America on the rise was simply not much interested, and Hollywood was too wise to stray far from its audience. Although still generally treated sympathetically, the poor were usually not treated at all. Since the blaxploitation movies and Do the Right Thing, though, the urban poor have returned -- with a vengeance, typically in the form of the underclass.

The social role assigned to the movie underclass, however, had changed. During the 1960s and 1970s, radical writers and activists had redefined the underclass as romantic heroes confronting an oppressive and corrupt socioeconomic order, and this redefinition had seeped into the general discourse. By the 1990s, this theme, with the violence that gave it birth mostly forgotten and its revolutionary implications scrubbed off, was driving film after film.

These black ghetto films and their non-black progeny seem very different from the urban poverty films of prior eras, partly because sex, violence, and profanity are today present in grand and explicit profusion. If earlier movies also tended to humanize the underclass, they nearly always reminded us that crime does not pay. The films of the 1990s and after often lack this element of reflexive condemnation. Their characters may exhibit gross social pathologies, but in emphasizing the injustices and suffering responsible for these behaviors, the movies assign the underclass no more blame than the conventional, upright deserving poor of years past. Reconceived as rebels, the underclass is driven to wrongdoing by forces beyond its control. Their members are action heroes waging war against a venal social/political system. In this structural apparatus, fault largely lies elsewhere. Again paraphrasing Keynes, the defunct radical views of decades ago reemerged in the movies. Rejected as analysis, they became accepted as didactic entertainment, for "cinema assumes a pedagogical role in the lives of many people" (hooks 2).

79 In this scenario, the state as personified by police, correction officers, or public officials is rarely at center stage. Its actions may be harsh, ineffective, or unjust, but its role in the tale is always secondary. Indeed, it is the basic irrelevance of the state that spurs much of the crime, and not only in the obvious sense that the indifference of the police creates criminal opportunities. Additionally, the state is felt by the underclass to have abandoned its obligation to impose moral order, in effect inviting them to assume the function. Thus, while some of their crime may be written off to greed or sadism, much of it, as Black put it in a classic article, "is moralistic and involves the pursuit of justice" (Black 34). A killing, for example, may be conceived as proper retribution for some prior offense; it not only balances the scales, but contributes through its deterrent value to the creation of moral order.

80 What the films' inattention to the state also implies is that the state has failed to meet its obligations under a neo-Lockean social compact: the people agree to obey the law and lead a conventional, productive life, and in return the state commits to respect their rights and dignity and ensure at least a minimum level of material well being. With the compact abrogated, the underclass are free to hunt their prey. If third parties suffer, this is dismissed as so much unavoidable collateral damage.

81 More recently underclass movies have contested the proposition that the society's injustice is irremediable by highlighting the American Dream of economic and social advancement through hard work and merit. Serious structural obstacles persist, of course, but with some talent and sufficient fighting spirit they can be vanquished. 
Perhaps the pessimism and self pity of the earlier period was thought to have run its course with audiences.

In either case, members of the movie underclass are emphatically not Hobsbawm's "social bandits," defending the underdog against the predations of the State and its privileged supporters, perhaps even robbing from the rich and giving to the poor. In democracies, Tocqueville predicted, "the poor conceive an eager desire to acquire comfort" (531), and as if a torrent rushing in to fill a void, fancy cars, designer clothes, and bejeweled watches become the measure of human worth in the ghettocentric underclass films. The outlaws, more acquisitive than the bourgeois, are regarded as heroes not simply because of their toughness and eagerness to confront the nefarious powers that be; equally significant is their style, as expressed in pure bling. Veblen might find this conspicuous consumption and pecuniary emulation at its most outlandish; culture defines needs, and so Cadillac Escalades and Cristal Champagne, aggressively displayed, announce that the owner has indisputably arrived - and the lavish parade never ends because the insecurity driving it never ends.

If all this constitutes a form of social protest, it is built on envy and resentment as much as on past grievances. Instead of defending an old moral order or championing a new one, these characters are defiantly self interested and explicitly amoral. They seek not to destroy or overturn the system, but merely to bend it to their advantage, and in this way establish their own worth. Shrewd rather than analytically sophisticated, they tend to focus much more on immediate personal goals than on any larger social agenda. If they are soldiers in a class war, they often seem unaware of this role that politically attuned viewers may ascribe to them. Instead, they appear preoccupied with the pursuit of happiness. Not wisdom or virtue or salvation, whose reverberations from earlier times can barely be heard. But happiness, now read (in defiantly un-Jeffersonian terms) as honored by friends, respected by foes, and pleasured by every worldly vice. Legal restraints and the bourgeois ethic of denial, as obstacles in the path, have no place here. Rather, happiness is to be pursued by any means necessary. Laid against this, the cause of political revolution has almost no commercial potential.

Protagonists in the newer underclass films, such as Hustle and Flow and Precious, lack this impulsive and violent hedonism, confronting a society less harsh in its hostility or indifference. But in either case, underclass movies have overwhelmingly been sympathetic toward underclass characters, regardless of their behavior. Perhaps, this merely echoes Mme. de Staal's truism that to understand all is to forgive all. We know the characters and see how an environment they did not create has conspired against them; we know that they are responsible for their conduct in the obvious sense that their choices determined how they behaved; but we also know that it was an unjust society that placed them in a context where these choices seemed to make sense. Yet the facile explanation that the protagonists are portrayed positively because Hollywood believes that the audience must identify with them leaves unanswered the question, Why select the underclass as protagonists? (It must also be said that occasionally underclass protagonists are depicted very unsympathetically, e.g., White Heat, 1949.)

Schumpeter had famously hypothesized that "capitalism creates a critical frame of mind which, after having destroyed the moral authority of so many other institutions, in the end turns against its own [and] goes on to attack ... the whole scheme of bourgeois values" (Schumpeter 143, 160). Yet the underclass movies, especially the Hollywood studio movies, were no more anti-capitalist than were the Mao jackets of 
the same period. Rather, they illustrate that capitalism will seek out every opportunity for profit, even if the opportunity embodies hostility to capitalism itself. Is this because capitalism teaches firms to focus on profit to the exclusion of all else? Or does it reflect an unexamined belief that the system is so entrenched that this hostility can never amount to much? Or is it founded on the faith that movies are mere entertainment, with no larger consequences? Succeeding decades, after all, would see movie corporations producing film after film purporting to demonstrate the ubiquitous evil of corporations.

The positive and, indeed, often celebratory vision of the movie underclass persisted in an era, in which many political leaders and pundits -- Reagan and Gingrich, the Christian right, Bush and DeLay, Limbaugh and O'Reilly -- relentlessly applauded sentimentalized family values, implicitly (and sometimes explicitly) attributing poverty to the absence of these values. And this, in turn, was reflected in an official disdain toward redistribution in favor of the poor (in the welfare reform of 1994, for example, and in the tax cuts of 2001) that had not been seen for generations. Even the Great Recession beginning in 2008 did not give birth to overwhelming popular demand for radical redistribution. Following in the wake of innumerable public discussions of inequality a 2011 Pew survey found that fewer than half the respondents thought income inequality was a problem "that needs to be fixed" or that federal policies reducing the gap were "extremely" or "very" important or that the rich became wealthy as a consequence of family money or connections (Morin). At the same time, another survey revealed that only about a third of the respondents thought government does not regulate business enough (Norris).

Yet movies have not rung the anti-redistributivist bell. Why, during the quarter century of conservative ascendancy, did movies not follow election returns? One reason is that polls have consistently shown that the public tends to take a much less punitive attitude toward the poor than do conservative Republicans. If most Americans continue to "hate welfare because they view it as a program that rewards the undeserving poor" (Gilens), most also continue to believe that "government should respond" (Page and Jacobs 14) to mitigate hardship and misery. Moviemakers understand this, and do not see an audience for anti-poor films. More generally, the poor and underclass are featured when moviemakers believe there is a market for these themes. When the urban poor constituted the heart of the audience, movies tended to focus on their plight. Afterwards, they seemed to melt away, save for a few films here and there that seemed impervious to trends. Why, then, the interest over the past two decades?

Initially, modern underclass movies were African American movies aimed mainly at African American audiences, a niche sizable enough to generate an entire genre. As accouterments of the African American underclass began to be de rigueur among young white audiences, who without irony imported gangsta rap and backward ball caps to suburbia, underclass movies have come to be made (usually with white characters) for white audiences, as well. For many of these movies, the angle of vision remained unchanged: the underclass is still seen as outsiders, victims of the system, human evidence of its mendacity and oppression. This is an underclass marked by defiance and estrangement, by contempt for hypocrisy and boredom with tradition, by preoccupation with status and avoidance of shame, by exuberant physicality and ravenous craving for sex, by focus on today and disregard for tomorrow. All these 
qualities denote a no-holds-barred celebration of teen values and the teenage experience, and this is no accident, for moviemakers understand that teenagers constitute a huge slab of the movie going public. Equally important, they are also the chief customers for such ancillary products as soundtracks, video games, video purchases and rentals, and licensed clothing and accessories, for which movies serve as elaborate marketing instruments. Newer than new, these underclass movies continue a venerable friendliness to the poor and a romanticization of rebellion and alienation that has been a theme in American movies almost since their inception.

Other underclass movies have come to strike a more hopeful theme, as underclassness is somehow transmuted into ambition and hard work that leads to success, rather conventionally constructed. As it has matured, the concept of the underclass has become sufficiently capacious to encompass both pessimistic and optimistic narratives.

Where these newer narratives differ from the old is that while earlier audiences probably knew of poverty first hand -- if they were not poor, they were at least acquainted with the poor -- much of today's audience knows the underclass only as a mythic creation. Mirroring the trickle down consumption patterns of gangstas emulating their betters are bubble-up consumption patterns of middle class suburban youths addressing their pals with "Yo!" and wearing low-hanging baggy pants and backward ball caps. Perhaps, the suburban teen knows the urban underclass in the same way that his Brooklyn grandfather knew cowboys. Thus have movies created virtual realities, which, in turn, have created movies, which, however realistic in intent, never resemble anything so much as other movies.

\section{BIBLIOGRAPHY}

Alex-Assensoh, Yvette. "Myths about Race and the Underclass." Urban Affairs Review. 31.1 (1995): 3-19.

Alinsky, Saul. The War on Poverty -- Political Pornography. Washington: Institute for Policy Studies, 1965.

Archibold, Randal C. "Gangland Bus Tour, with Lunch and a Waiver." New York Times, 16 January 2010, 16 January 2010.

Auletta, Ken. The Underclass. New York: Random House, 1982.

Barlow, Melissa H. "Race and the Problem of Crime in Time and Newsweek Stories." Social Justice. 25.2 (1998): 149-83.

Benjamin, Walter. Das Kunstwerk im Zeitalter Seiner Technischen Reproduzoerbarlkeit. Frankfurt aM: Suhrkamp Verlag, 1936.

Black, Donald. “Crime as Social Control.” American Sociological Review. 48:1 (1983): 34-45.

Blauner, Robert. “Internal Colonialism and Ghetto Revolt.” Social Problems,. 16.4 (1969): 393-408. 
. "Whitewash over Watts." Mass Violence in America. Ed. Robert M. Fogelson. New York: Arno, 1969.

“Blood Will Tell.” Saturday Evening Post, 21 March, 1925: 30.

Bogle, Donald. Toms, Coons, Mulattoes, Mammies, and Bucks. New York: Continuum, 1994.

Bourdieu, Pierre. A Social Critique of the Judgement of Taste. London: Routledge, 1984.

Bourget, Jean-Loup. “Social Implications in the Hollywood Genres.” Journal of Modern Literature, 3.2 (1973): 191-200.

Brigham, Carl C. A Study of American Intelligence. Princeton UP, 1922.

Brown, Claude. Manchild in the Promised Land. New York: Macmillan, 1965.

Burke, Peter. The French Historical Revolution. Stanford: Stanford UP, 1995.

Chicago Tribune. The American Millstone. New York: McGraw-Hill, 1986.

Cloward, Richard A., and Lloyd E. Ohlin. Delinquency and Opportunity. New York: Free Press, 1961.

Cohen, Stanley. Folk Devils and Moral Panics. London: MacGibbon and Kee, 1973.

Commager, Henry Steele. The American Mind. New Haven: Yale UP, 1950.

Cook, Fay L., and Edith J. Barrett. Support for the American Welfare State. New York: Columbia UP, 1992.

Cutler, David M., and Edward L. Glaeser. “Are Ghettos Good or Bad?” Quarterly Journal of Economics,. 112.4 (1997): 827-72.

Dalton, Patricio S., Ghosal, Sayantan, and Anandi Mani. Poverty and Aspiration Failure. CAGE Online Working Paper Series, 2010.

Davis, Peter. Hometown. New York: Columbia UP, 1992.

Dohan, Daniel. The Price of Poverty. Berkeley: U of California P, 2003.

Doherty, Thomas P. Pre-Code Hollywood. New York: Columbia UP, 1999.

Donohue, John J. III, and James Heckman. “Continuous versus Episodic Change.” Journal of EconomicLiterature,. 29.4 (1991): 1603-43.

Dreiser, Theodore. Sister Carrie.1900 Toronto: Bantam, 1958.

Drury, S.S., Theall, K., Gleason, M.M., Smyke, a.T., DeVivo, I., Wong, J.y.Y., Fox, N.A., Zeanah, C.H., and C.A. Nelson. "Telomere Length and Early Severe Social Deprivation." Molecular Psychiatry. 17.1 (2012): 719-27.

Dynes, Russell, and E.L. Quarantelli. "What Looting in Civil Disobedience Really Means.” Transaction 5.5 (May 1968): 9-14.

Ebert, Roger. Awake in the Dark. Chicago: U of Chicago P, 2006.

Edin, Kathryn, and Maria Kefalas. Promises I Can Keep. Berkeley: U of California P, 2005.

Elias, Norbert. Uber den Prozess der Zivilisation. Basel: Haus zum Falken, 1939.

Emerson, Ralph Waldo. Collected Works. Eds. Robert E. Spiller et al. Cambridge: Belknap, 1971.

Emery, Robert J. The Directors. New York: TV Books, 1999.

Farley, Reynolds, and Walter R. Allen. The Color Line and the Quality of Life in America. New York: Russell Sage Foundation, 1987. 
Fine, Ben. The World of Consumption,2nd ed. London: Psychology Press, 2002.

Fletcher,Jonathan. Violence and Civilization. Cambridge: Polity, 1997.

Gilens, Martin. Why Americans Hate Welfare. U of Chicago P, 1999.

Ginsburgh, Victor, and Sheila Weyers. "On the Perceived Quality of Movies.” Journal of

CulturalEconomics. 23.2 (1999): 269-83.

Gitlin, Todd. "The Radical Potential of the Poor." International Socialist Journal. 24.1(1967): 24-30.

Glazer, Nathan, and Daniel Patrick Moynihan. Beyond the Melting Pot. Cambridge: MIT P, 1963.

Goode, Erich, and Nachman Ben-Yehuda. Moral Panics. New York: Wiley, 1994.

Gordon, Linda. "Introduction." Women, the State, and Work. Ed. Linda Gordon. Madison: U of Wisconsin P, 1990.

Goren, Paul. "Race, Sophistication, and White Opinion on Government Spending." Political Behavior. 25.2 (2003): 201-20.

Governor's Commission on the Los Angeles Riots. Violence in the City - An End or a Beginning? December 2, 1965.

Griffin, Junius. "Hollywood and the Black Community.” The Crisis, May 1973: 171.

Grodzins, Morton. The Metropolitan Area as a Racial Problem. Pittsburgh: U of Pittsburgh P, 1958.

Guerrero, Ed. Framing Blackness. Philadelphia: Temple UP, 1993.

Hall, Stuart et al. Policing the Crisis. London: Macmillan, 1978.

Hamilton, Brady E., Martin, Joyce A., and Stephanie J. Ventura. "Births: Preliminary Data for 2009." National Vital Statistics Reports. 59.3 (2010).

Harrington, Michael. The Other America. New York: Macmillan, 1962.

Hirschberg, Lynn. “The Audacity of 'Precious.” New York Times Magazine, 25 October 2009:28-37, 68.

Hobsbawm, E.J. Primitive Rebels. Manchester: Manchester UP, 1959.

Holt, Henry. Garrulities of an Octogenarian. Boston: Houghton, Mifflin, 1923.

hooks, bell. Reel to Real. New York: Routledge, 1996.

Horowitz, Daniel. Consuming Pleasures. Philadelphia: U of Pennsylvania P, 2012.

Jacobs, Jane. The Life and Death of Great American Cities. New York: Random House, 1961.

Jacobson, Matthew F. Whiteness of a Different Color. Cambridge: Harvard UP, 1998.

Jencks, Christopher. “Deadly Neighborhoods.” New Republic, 13 June 1988: 23-32.

Jones, Margaret B. Love and Consequences. New York: Riverhead, 2008.

Karmen, Andrew. New York Murder Mystery. New York: NYU P, 2000.

Karp, Ivan. “Agency and Social Theory. “American Ethnologist, 13.1(1986): 131-37.

Keynes, John Maynard. The General Theory of Employment, Interest and Money. New York: Harcourt, Brace, 1936.

Koerner, B.I., "I Shot the Polo Shirt.” New York Times. 8 July 2007. 8 July 2007.

Kuhn, Thomas S. The Structure of Scientific Revolutions. U of Chicago P, 1962. 
Lancaster, John. “Next Stop Squalor.” Smithsonian. March (2007): 96-105.

Lea, John and Jock Young. What Is to Be Done about Law and Order? London: Pluto, 1984.

Lears, T. Jackson. "Beyond Veblen," Marketing, Vol. II. Eds. Stanley C. Hollander and Kathleen M.. Russell. Aldershot: Elgar, 1993, 27-40.

Lee, Spike. Do the Right Thing. New York: Fireside, 1989.

Lemann, Nicholas. “The Origins of the Underclass.” Atlantic. June: 31-55 and July (1986): 65-68.

LeRoy, J.T. The Heart Is Deceitful above All Things. New York: Bloomsbury, 2001.

Levy, Frank. How Big Is the Underclass? Washington: Urban Institute, 1977.

Levy, Jacob. Freaks of Fortune. Cambridge: Harvard UP, 2013.

Lewis, Hilton. "Culture of Poverty? What Does It Matter?" The Culture of Poverty. Ed. Eleanor B. Leacock. New York: Simon and Schuster, 1971.

Lewis, Oscar. “The Culture of Poverty.” Scientific American. 215.1 (1966): 19-25. The Children of Sanchez. New York: Random House, 1961.

Lewis, Sinclair. Babbitt. New York: Harcourt, Brace, 1922.

Lowenstein, G. “The New Underclass.” Sociological Quarterly, 26.1(1985): 35-48.

Long, Norton. "The City as Reservation." Public Interest (February, 1971): 22-38.

Ludwig, Jens, Duncan, Greg S., Gennetian, Lisa A., Katz, Lawrence F., Kessler, Ronald C., King, Jeffrey R., and Lisa Sanbonmatsu. "Neighborhood Effects on the Long-Term Well-Being of LowIncome Adults.” Science. 337 (2012): 1505-1510.

Magnet, Myron. The Dream and the Nightmare. New York: Encounter, 1993.

Mailer, Norman. “The White Negro.” Dissent. 4:3 (1957) , Kurlansky, Mervyn, and Jon Naar. The Faith of Graffiti. New York: Praeger, 1974.

Marx, Karl. Capital. 1883.Trans. Samuel Moore and Edward B. Aveling. Ed. Frederick Engels. London: Laurence and Wishar, 1961 and Frederick Engels. Selected Works: vol. I. 1851.Trans. Samuel Moore and Edward B. Aveling. London: Laurence and Wishar, 1962 Massey, Douglas S., and Nancy A. Denton. American Apartheid. Cambridge: Harvard UP, 1993. McClosky, Herbert, and John Zaller. The American Ethos. Cambridge: Harvard UP, 1984.

McCord, William et al. Lifestyles in the Ghetto. New York: Norton, 1969.

Mead, Lawrence M. Beyond Entitlement. New York: Free Press, 1986.

Mencken, H.L. Prejudices, second series. New York: Knopf, 1920.

Mincy, Ronald B. Black Males Left Behind. Washington: Urban Institute, 2006.

Morin, Richard. "Rising Share of Americans See Conflict between Rich and Poor." Pew Research Center. 11 January 2012.

Murray, Charles. Losing Ground. New York: Basic, 1984. . Coming Apart. New York: Crown Forum, 2012.

Muse, Wendi. “Ghetto Chic.” Racialicious.com (24 May 2007). 
Muzzio, Douglas. “The Urban Basement Revisited.” Urban Affairs Review. 25.3 (1989): 352-65. “The Smell in the Urban Basement." Urban Affairs Review. 19.1(1983):133-43.

Myrdal, Gunnar. Challenge to Affluence. New York: Pantheon, 1963.

Nanni, V., Uher, R., and A. Danese. "Childhood Maltreatment Predicts Unfavorable Course of Illness and Treatment Outcome in Depression: A Meta-Analysis." American Journal of Psychiatry. 169: 141-151 (2012).

National Advisory Commission on Civil Disorders. Report. Washington: Government Printing Office, 1968.

Nathan, Richard P. “Will the Underclass Always Be with Us?” Society 24 (March, 1987):57-62.

Nocera, Joe. “Rooting for Santorum.” New York Times, 3 March 2012, 3 March 2012.

Norris, Floyd. "How the Public Sees Business Rules." New York Times, 28 January 2012, 28 January 2012.

Olasky, Marvin N. The Tragedy of American Compassion. Washington: Regnery Gateway, 1992.

Orfield, Gary H. Dropouts in America. Harvard UP, 2006.

Patterson, James T. America's Struggle against Poverty, 1910-1985. Cambridge: Harvard UP, 1986.

Patterson, Orlando. "Poverty of the Mind." New York Times. 26 March 2006, 26 March 2006.

Pernick, Martin S. The Black Stork. New York: Oxford UP, 1996.

Piven, Frances Fox. and Richard A. Cloward. Regulating the Poor. New York: Pantheon, 1971.

Poitier, Sidney. This Life. New York: Knopf, 1980.

President's Commission on Law Enforcement and the Administration of Justice. The Challenge of Crime ina Free Society. Washington: Government Printing Office, 1967.

Rawls, John. A Theory of Justice. Cambridge: Harvard UP, 1970.

Reed, Adolph L. Stirrings in the Jug. Minneapolis: U of Minnesota P, 1999.

Reissman, Frank. “Low Income Culture.” Journal of Marriage and the Family. 26.3 (1964): 417-21.

Riis, Jacob. How the Other Half Lives. New York: Scribner, 1890.

Roberts, Sam. "A Striking Evolution in Bedford-Stuyvesant as the White Population Soars." New YorkTimes, 5 August 5 2011, 6 August 2006.

Rodman, Hyman. "Failure and Social Pathology in the Ghetto." Science. 161(1968): 756-62.

Rousseau, Jean-Jacques. A Discourse on the Origin of Inequality and A Discourse on Political Economy. 1754.Translated G.D.H. Cole. Stillwell, KS: Digireads, 2006.

Ryan, William. Blaming the Victim. New York: Vintage, 1971.

Sanchez, Sonia. We a BaddDD People. Detroit: Broadside, 1970.

Sanders, James. Celluloid Skyline. New York: Knopf, 2001.

Sanger, Margaret. The Pivot of Civilization. New York: Putnam, 1922.

Seligman, Ben B. Permanent Poverty. Chicago: Quadrangle, 1968.

Shalev, Idam, Moffitt, Terrie E., and Avshalom Caspi. "Childhood Trauma and Telomere

Maintenance," European Journal Psychotraumatology. 3(2012). 
Shefter, Martin. Images of the City in Political Science." Cities of the Mind. Eds. Lloyd Rodwin and Robert M. Hollister. New York: Plenum, 1974.

Silk, Catherine, and John Silk. Popular Racism and Anti-Racism in American Culture. Manchester UP, 1990.

Small, Mario Lewis, Harding, David J., and Lamont, Michele. "Reconsidering Culture and Poverty." Annals, 629.1(2010): 6-27.

Sowell, Thomas. American Ethnic Groups. Washington: Urban Institute, 1974.

Starr, Kevin. Golden Dreams. New York: Oxford UP, 2009.

Stevenson, Betsey, and Justin Wolfers. "Subjective and Objective Indicators of Racial Progress." Unpub. paper, Wharton School, University of Pennsylvania.

Thomas, Piri. Down These Mean Streets. New York: Knopf, 1967.

Tocqueville, Alexis de. Democracy in America. 1835. Trans. George Lawrence. Garden City: Anchor, 1969.

Trapp, June L. and Arthur H. Roberts. "Hard Core Unemployment." Trans-action 7.9 (September, 1970)

Trebay, Guy. "In Jailhouse Chic, an Anti-Style Turns into a Style.” New York Times, 13 June 2007. 13 June 2007.

Tyner, James A. "Defend the Ghetto." Annals of the American Association of American Geographers. 96.1 (2006):105-18.

Valentine, Charles A. Culture and Poverty. U of Chicago P, 1968.

Veblen. Thorstein. The Theory of the Leisure Class. New York: Macmillan, 1912.

Wasquaint, Loic J.D. “Three Pernicious Premises in the Study of the American Ghetto." Gangs inthe Global City. Ed. John M. Hagedorn. Urbana: U of Illinois P, 2007, 34-53.

Ward, Lester. "Eugenics, Euthenics, and Eudemics." American Journal of Sociology. 18.4 (1913): 737-54.

Warner, Amos G. American Charities. New York: Crowell, 1894.

Wegman, H.L., and C. Stetler. "A Meta-Analytic Review of the Effects of Childhood Abuse on Medical Outcomes in Adulthood." Psychosomatic Medicine 71: 805-812.

Wellman, David. “The Wrong Way to Find Jobs for Negroes.” Society 5.5 (April, 1968): 9-18.

Whisler, Leah. Def Jam Recordings. New York: Rizzoli, 2011.

White, Kyle Powys, Selinger, Evan, and Outterson, Kevin. "Poverty Tourism and the Problem of Consent." Boston University School of Law Working Paper No. 11-22, 24 May 2011.

Wilson, William Julius. More than Just Race. New York: Norton, 2009.

.The Truly Disadvantaged. U of Chicago P, 1987.

Wolfe, Tom. "Radical Chic.” New York, 8 June 1969: 26-56.

X, Malcolm with Alex Haley. The Autobiography of Malcolm X. New York: Ballantine, 1965.

Young, Alfred. The Minds of Marginalized Black Men. Princeton UP, 2004. 


\section{NOTES}

1. The culture of poverty thesis unfairly blames the victims, some say (see Valentine; Ryan); or points paternalistically at their attitudes and behaviors (Reed 195-96); or erroneously posits that values drive behavior and that the poor and middle class exhibit substantially different values (Young; Dohan; Edin and Kefalas); or serves as a "convenient rationalization" (Rodman 759) that "diverts energies and attention from the need for significant changes in the educational, occupational, and political structures" (H. Lewis 353). The culture of poverty thesis more recently has been rather radically reworked in order to shed its earlier normative implications (Small, Harding, and Lamont), though there is little reason to believe that the newer versions have been widely adopted outside a few sectors of academia.

2. The shortcomings of this definition are obvious. The old Andy Warhol crowd also rejected mainstream values and virtues, as did the Collyer brothers, and they hardly qualify as members of the underclass. Too, the underclass' rejection of these values is only partial: temperance and thrift may be discarded but certainly not acquisitive materialism.

3. Though hip-hop may have originated in the South Bronx, its founding father Russell Simmons observed that in the late 1970s and early 1980s the music was welcomed in white clubs "before the black clubs, MTV before BET, the rock press before the black press. That was the development process for hip-hop" (qtd. in Whisler 43).

\section{ABSTRACTS}

“Menace II Society?" investigates cinematic portrayals of American urban poverty and the urban underclass as part of an ongoing public discourse on the nature of the urban poor, the causes and conditions of their poverty, and the appropriate responses from society. Movies have tended to portray poverty as environmentally caused and sustained, often directing ambitious characters toward criminality with a to-understand-all-is-to-forgive-all logic. During the silent and Depression eras, movies featured the urban poor prominently, but afterwards their role drastically shrunk and did not regain its place until the black underclass films of the 1990s, which, in a softened version of " 60 s radical critiques, redefined the deserving poor as rejecting the dominant socioeconomic system in favor of an often hedonistic rebellion. Subsequent white underclass movies followed this pattern, but more recently the American Dream has reasserted itself in popular underclass films, sounding a more positive note.

\section{AUTHOR}

THOMAS HALPER AND DOUGLAS MUZZIO

Baruch College/City University of New York 